\title{
STUDIES IN SPINA BIFIDA CYSTICA III. SEASONAL VARIATION IN THE FREQUENCY OF SPINA BIFIDA BIRTHS
}

\author{
BY \\ A. N. GUTHKELCH \\ From the Royal Manchester Children's Hospital, Pendlebury, Lancs.
}

This communication continues the analysis of data accumulated from a series of cases of spina bifida cystica observed during the years 1949 to 1958. In earlier papers, attention was drawn to the magnitude of the problem presented by these cases and to the amount of medical and surgical care which they require (Doran and Guthkelch, 1961) and to certain complications which need consideration in planning the surgical repair of the spinal defect (Guthkelch, 1962).

Other workers (McKeown and Record, 1951; Edwards, 1958) have looked for a seasonal incidence in spina bifida births but have failed to find one. But the same workers have demonstrated clearly that there is a considerable seasonal variation in the frequency of anencephalus births, the winter incidence of which is about a third as great again as the summer incidence, and there is every reason to suppose that anencephalus and spina bifida are two aspects of a fundamentally similar disorder, that is to say a failure of closure of the primitive neural plate during early embryonic life. It is well known that anencephalus and the grosser forms of spina bifida often occur in the same individual and indeed complete craniorachischisis is not a rare human malformation. Warkany (1960) has drawn attention to the fundamental similarity of the pathological changes which are seen in experimental spina bifida and anencephaly in the rat. For this reason, it seemed desirable to search our own material and that previously published, in order to see whether any seasonal trend could be observed in the incidence of spina bifida similar to that already established for anencephalus.

McKeown and Record (1951) set out the monthly figures for spina bifida still-births in Scotland between 1939 and 1946 in detail (Table I). They suggested that the incidence of spina bifida still-births per thousand births for each month of the year
TABLE I

MONTHLY STILL-BIRTH RATES ATTRIBUTED TO SPINA BIFIDA, SCOTLAND, 1939-46. After McKeown and Record (1951)

\begin{tabular}{|c|c|c|c|}
\hline \multicolumn{2}{|c|}{ Month of Birth } & Spina Bifida Cases & Mean \\
\hline $\begin{array}{l}\text { December } . \\
\text { January } \\
\text { February } \\
\text { March } \\
\text { April } \\
\text { May }\end{array}$ & $\begin{array}{l}\cdots \\
\cdots \\
\cdots \\
\cdots\end{array}$ & $\begin{array}{l}0.53 \\
0.56 \\
0.48 \\
0.48 \\
0.55 \\
0.53\end{array}$ & 0.52 \\
\hline $\begin{array}{l}\text { June } \\
\text { July } \\
\text { August } \\
\text { September } \\
\text { October } \\
\text { November. . }\end{array}$ & $\begin{array}{l}. . \\
\because \\
\because \\
\ldots\end{array}$ & $\begin{array}{l}0.47 \\
0.28 \\
0.40 \\
0.43 \\
0.40 \\
0.43\end{array}$ & $0 \cdot 40$ \\
\hline
\end{tabular}

showed no significant variations. But when one considers their figures, it appears that, although the variations are not large, none the less the rate of spina bifida still-births is higher in each month between December and May inclusive than in any of the remaining months of the year. This would be in accord with the hypothesis that infants conceived during the Spring and Summer are somewhat more likely to suffer from spina bifida than those conceived in the Autumn and Winter. Application of the $t$-test to the figures noted shows that the difference between the two parts of the year has a high level of significance $(P<1$ per cent.).

The month of the last menstrual period of mothers who gave birth to anencephalics in Scotland between 1939 and 1946 is not known, but the monthly birth rates of this deformity show variations in Birmingham between 1940-47 similar to those occurring in Scotland, and the figures given by McKeown and Record (1951) for the dates of conception of anencephalics in Birmingham (1940-47) show a maximum variation between the half year March-August (high) 
and the half year September-February (low). Now spina bifida babies are much less often born prematurely than anencephalics, the actual figures being 16 and 64 per cent. respectively (Record and McKeown, 1949). Consequently, since the half year of high birth rate for spina bifida in Scotland from $1939-46$ is, as shown by Table I, December to May, the 6 months of high-conception rate for the same deformity can reasonably be assumed to be from March to August, and is therefore the same as for the anencephalics conceived during the same years.

The same relationship can be shown in a slightly different way, as follows:

The greater frequency of prematurity amongst anencephalics compared with spina bifida babies should have the effect of advancing, for all pregnancies with the same dates of conception, the dates of delivery of the anencephalics by about 2 months, so that the dates of conception of anencephalics born in October should correspond to those of spina bifida babies born in December, and so on. Table II shows the result of comparing the monthly figures for anencephalus and spina bifida births in this way. They are in fact quite highly correlated $(P<1$ per cent.).

TABLE II

MONTHLY SPINA BIFIDA AND ANENCEPHALUS STILL-BIRTH RATES PER 1,000 TOTAL BIRTHS, SCOTLAND, 1939-46

After McKeown and Record (1951)

\begin{tabular}{|c|c|c|c|c|}
\hline \multicolumn{3}{|c|}{ Spina Bifida } & \multicolumn{2}{|c|}{ Anencephalus } \\
\hline Month & & $\begin{array}{c}\text { Rate per } \\
1,000 \text { Births }\end{array}$ & Month & $\begin{array}{c}\text { Rate per } \\
\text { 1,000 Births }\end{array}$ \\
\hline $\begin{array}{l}\text { January } \\
\text { February } \\
\text { March } \\
\text { April .. } \\
\text { May . . } \\
\text { June . . } \\
\text { July . } \\
\text { August } \\
\text { September } \\
\text { October } \\
\text { November } \\
\text { December }\end{array}$ & $\begin{array}{l}\cdots \\
\cdots \\
\cdots \\
\cdots \\
\cdots \\
\cdots \\
\cdots \\
\cdots \\
\cdots\end{array}$ & $\begin{array}{l}0.56 \\
0.48 \\
0.48 \\
0.55 \\
0.53 \\
0.47 \\
0.28 \\
0.40 \\
0.43 \\
0.40 \\
0.43 \\
0.53\end{array}$ & $\begin{array}{l}\text { November } \\
\text { December } \\
\text { January } \\
\text { February } \\
\text { March } \\
\text { April } \\
\text { May } \\
\text { June } \\
\text { July .. } \\
\text { August } \\
\text { September : } \\
\text { October }\end{array}$ & $\begin{array}{l}2 \cdot 90 \\
3 \cdot 09 \\
2 \cdot 92 \\
2 \cdot 98 \\
2 \cdot 44 \\
2 \cdot 27 \\
1.91 \\
2 \cdot 29 \\
1.94 \\
2 \cdot 37 \\
2 \cdot 48 \\
2 \cdot 69\end{array}$ \\
\hline
\end{tabular}

$\begin{aligned} r & =729 \\ \text { d.f. } & =11\end{aligned}$

$P<1$ per cent.

The Manchester Data

Out of the 307 patients born with spina bifida cystica who formed the subject of the general survey (Doran and Guthkelch, 1961), there were 259 born between the years 1949 and 1958, whose date of birth is known with certainty, and whose parents resided either in the City of Manchester itself or within a radius of about 15 miles. The number of births in each month of the year is set out in Table III. On looking at the period December to May which has already been indicated by the data of McKeown and Record (1951), one can see that there is a considerable excess of spina bifida births. The mean number of spina bifida births during these 6 months is in fact $24 \cdot 67$, compared with $18 \cdot 5$ for the remaining 6 months of the year. Application of the $t$-test to the figures suggests that the difference between them is significant $(P \sim 4$ per cent.).

TABLE III

MONTHLY NUMBERS OF CASES OF SPINA BIFIDA BIRTHS REFERRED TO THE ROYAL MANCHESTER CHILDREN'S HOSPITAL, 1949-58

\begin{tabular}{|c|c|c|c|}
\hline \multicolumn{2}{|c|}{ Month of Birth } & $\begin{array}{c}\text { Number of } \\
\text { Spina Bifida Births }\end{array}$ & Mean \\
\hline 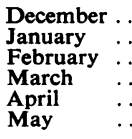 & $\begin{array}{l}\ldots \\
\cdots \\
\cdots \\
\cdots \\
\cdots\end{array}$ & $\begin{array}{l}17 \\
27 \\
29 \\
25 \\
29 \\
21\end{array}$ & $24 \cdot 67$ \\
\hline $\begin{array}{l}\text { June } \\
\text { July } \\
\text { August } \\
\text { September. } \\
\text { October } \\
\text { November. }\end{array}$ & $\begin{array}{l}\ldots \\
\ldots \\
\ldots \\
\ldots \\
\ldots\end{array}$ & $\begin{array}{l}14 \\
23 \\
15 \\
22 \\
25 \\
12\end{array}$ & $18 \cdot 5$ \\
\hline Total & . & 259 & \\
\hline
\end{tabular}

However, as in Scotland, so in Manchester, there is of course some variation in the total number of live births from month to month. It is impossible to make an accurate allowance for this because the sample under consideration does not represent the total number of spina bifida births in any one place, but simply the number of such cases referred to a single neurosurgeon working in a children's hospital in the area concerned. But it was found that the largest single contribution to the total number of cases was made up of infants born within the City of Manchester, so figures were obtained for the total live-births for the City of Manchester during each month of the period under review and the monthly numbers of spina bifida births were corrected in such a way as to take account of the total monthly livebirth rate. The calculation involves the assumption that the seasonal variation in the total birth rate for the various towns around Manchester from which cases of spina bifida were seen does not differ greatly in the aggregate from that observed for the City of Manchester itself, but this is believed to be in accordance with the facts. Making the allowance suggested (Table IV), we find that the proportion of infants 
TABLE IV

MONTHLY NUMBERS OF SPINA BIFIDA BIRTHS (HOSPITAL CASES), ADJUSTED FOR MONTHLY TOTAL LIVE-BIRTH RATE, 1949-58

\begin{tabular}{|c|c|c|c|c|}
\hline $\begin{array}{l}\text { Month } \\
\text { of Birth }\end{array}$ & $\begin{array}{l}\text { Total Monthly } \\
\text { Live-Births (B) }\end{array}$ & $\begin{array}{l}\text { Observed Spina } \\
\text { Bifida Births (S) }\end{array}$ & $\frac{10,000 S}{B}$ & Mean \\
\hline $\begin{array}{l}\text { December } \\
\text { January } \\
\text { February } \\
\text { March } \\
\text { April } \\
\text { May }\end{array}$ & $\begin{array}{r}9,645 \\
11,445 \\
10,234 \\
12,103 \\
11,174 \\
11,544\end{array}$ & $\begin{array}{l}17 \\
27 \\
29 \\
25 \\
29 \\
21\end{array}$ & $\begin{array}{l}17 \cdot 6 \\
23 \cdot 6 \\
28 \cdot 3 \\
20 \cdot 7 \\
26 \cdot 0 \\
18 \cdot 2\end{array}$ & $22 \cdot 4$ \\
\hline $\begin{array}{l}\text { June } \\
\text { July .. } \\
\text { August } \\
\text { September } \\
\text { October } \\
\text { November }\end{array}$ & $\begin{array}{l}11,316 \\
11,185 \\
11,127 \\
10,343 \\
10,885 \\
10,026\end{array}$ & $\begin{array}{l}14 \\
23 \\
15 \\
22 \\
25 \\
12\end{array}$ & $\begin{array}{l}12 \cdot 4 \\
20 \cdot 6 \\
13 \cdot 5 \\
21 \cdot 3 \\
23 \cdot 0 \\
12 \cdot 0\end{array}$ & $17 \cdot 1$ \\
\hline Total & 131,027 & 259 & & \\
\hline
\end{tabular}

with spina bifida born in the months December to May remains greater than the proportion born during the rest of the year, the difference being still at about the same level of significance $(P \sim 4$ per cent.).

\section{Discussion}

As has already been pointed out, the data presented in this paper differ considerably in kind from those already examined by McKeown and Record (1951) and by Edwards (1958). The Manchester figures do not give a complete picture of all the events relating to the birth of spina bifida babies either in Manchester itself or in any area of the North West of England. At best, they are no more than a sample, though there is reason to believe that it is a fair one. It has already been shown (Doran and Guthkelch, 1961) that the sex ratio of the series of cases studied, the proportion of simple meningocoeles to myelomeningocoeles and the anatomical situations of the malformations are closely in accord with those observed in other previously published series of cases.

As to the size of the sample, Record and McKeown (1949) suggested that spina bifida occurred with a frequency of about 2.49 per 1,000 live-births, although since their data related only to cases dying within the first year of life, and some cases presumably survived, the real figure may be rather higher. At any rate, it is probably safe to assume that 259 live-born cases of spina bifida would result from about 100,000 total live-births, and since the annual number of live-births within a radius of 15 miles from Manchester has recently been about 39,000- which implies 390,000 during the 10-year period under review - the series of cases presented here probably represents about a quarter of all the spina bifida live-births occurring in the Manchester area (as previously defined).

The monthly figures for Scottish spina bifida stillbirths show a greater excess between December and May than those for Manchester live-births. This may of course be a true biological difference, though another explanation is possible. Illness and shortage of staff restricted the winter admissions to the Neurosurgical Unit of the Royal Manchester Children's Hospital during two of the years under review. The winter figures for observed spina bifida births were low for these two years, and since most spina bifida cases are in fact referred for an opinion within a few weeks of birth, this is what would be expected if such an adventitious restriction of the normal input of cases were operating.

Recently, Edwards (1961b) has published figures for anencephalus and spina bifida births for Birmingham during the years 1946 to 1955 . These show an excess of anencephalus births during one half-year as against the other similar to those previously reported, but in this case the half-year of highest incidence runs from November to April instead of from October to March, while the monthly spina bifida birth rates show only a slight excess in the first as against the second half-year, one which taken by itself would be of no significance. Moreover, the magnitude of the seasonal variation in anencephalus births in Birmingham from 1946-55 is only half that observed both in Scotland from 1939-46 and, interestingly enough, in Birmingham from 1940-47 (McKeown and Record, 1951).

But it is also worth noting that, in Edwards's latest data, the month of highest incidence of anencephalic births is January and that of spina bifida births is March. This 2-month difference in phase is in accordance with the hypothesis presented in this paper.

It is hoped to extend the analysis of the Manchester data according to Edwards's method for the recognition of cyclic trends (Edwards, 1961a) in the near future. It would also be interesting to look for similar tendencies amongst the populations of cities in other latitudes, and particularly in the Southern hemisphere.

\section{SUMMARY}

Evidence is presented that, as has already been demonstrated for anencephalus, there are seasonal variations in the incidence of spina bifida births. 
Both for anencephalic and for spina bifida pregnancies, the period of the year in which conception is more likely to result in the production of an infant with one of these deformities is approximately the same.

I wish to thank Dr. C. Metcalfe Brown, Medical Officer of Health of the City of Manchester, who kindly provided the figures for live-births in the city, quoted in Table III, and also Mr. T. Lewis, of the Statistical Laboratory of the University of Manchester, for his advice.

\section{REFERENCES}

Doran, P. A., and Guthkelch, A. N. (1961). J. Neurol. Neurosurg. Psychiat., 24, 331.

Edwards, J. H. (1958). Brit. J. prev. soc. Med., 12, 115. (1961a). Ann. hum. Genet., 25, 83. (1961b). Ibid. 25, 89.

Guthkelch, A. N. (1962). J. Neurol. Neurosurg. Psychiat., 25, 137.

McKeown, T., and Record, R. G. (1951). Lancet., 1, 192.

Record, R. G., and McKeown, T. (1949). Brit. J. soc. Med., 3, 183.

Warkany, J. (1960). In "Mental Retardation", Proc. I. int. med. Conf., Portland, Maine, ed. P. W. Bowman and H. V. Mautner. Grune and Stratton, New York and London. 